\title{
Implementation of Internal Quality Assurance System (IQAS) in Maintaining Excellent Accreditation Levels
}

\author{
Emma Hermawati Muhari ${ }^{1}$, Herawati Budiastuti ${ }^{2}$, Fitria Yulistiani ${ }^{3}$, Alfiana Adhitasari ${ }^{4}$, \\ Tifa Paramitha ${ }^{5}$, Irwan Hidayatulloh ${ }^{6}$ \\ Chemical Engineering Department, Politeknik Negeri Bandung ${ }^{1,2,3,4,5,6}$ \\ \{emma.hm@polban.ac.id ${ }^{1}$, herabudi@polban.ac.id², fitria.yulistiani@polban.ac.id $\left.{ }^{3}\right\}$
}

\begin{abstract}
In determining the quality of study programs, the National Accreditation Board for Higher Education (BAN-PT) will implement the use of new criteria that make an internal quality assurance system (IQAS) an important pillar. One of Study Programs in Politeknik Negeri Bandung (Polban), has obtained an excellence accreditation but through the BAN-PT forms which did not require the implementation of IQAS. Research was carried out by descriptive and correlational methods to maintain the excellence accreditation in 2020 and subsequent years for this study program. Several weaknesses and improvements were obtained. Several Polban's IQAS documents have to be completed to include national criteria in accordance with the Minister of Research and Technology Regulation No. 44/2015 and 50/2018. The indicators in IQAS have to be completed in accordance with the mapping of internal standards results against the national standards and the study program accreditation assessment matrix.
\end{abstract}

Keywords: Accreditation, Study Programs, Internal Quality Assurance System

\section{Introduction}

The Internal Quality Assurance System (IQAS) is a system within (internal) higher education institutions that is independent (autonomous). This is stated in Law Number 12 year 2012 concerning Higher Education [1] which was followed up through Permenristekdikti Number 62 year 2016 [2] concerning the Internal Quality Assurance System. Therefore, the implementation of IQAS is a must for all universities in Indonesia.

In 2018, out of 4,643 tertiary institutions in Indonesia, only 1,189 (25.6\%) of tertiary institutions had completed mapping of IQAS implementation in their respective tertiary institutions [3]. If the tertiary education institutions are considered to be able to represent existing study programs, it means that only about $25.6 \%$ of study programs have mapped IQAS. Whereas starting on 1 April 2019, the study program accreditation will start to be implemented by using new criteria that make IQAS an important pillar. IQAS output becomes input for the National Higher Education Accreditation Agency (BAN-PT) or the Independent Accreditation Institute (LAM) in determining the status and ranking of accreditations [1].

The accreditation of a study program or educational institution is evidence of the implementation of its quality assurance system, which is measured through an external quality 
assurance system conducted by BAN-PT or LAM. Politeknik Negeri Bandung (Polban) currently has an A (excellent) accreditation rating both institutionally and 21 study programs from all study programs (37) possesed by Polban.

Polban and 21 study programs in Polban can obtain excellent accreditation rank (A) by implementing and conducting PIECI management (Planning, Implementation, Evaluation, Control and Improvement of Standards) in carrying out their respective IQAS. PIECI management includes management of Planning for establishing (P) Standards of Polban / Study Programs, Implementation (I) of Standards that have been set, Evaluation (E) of Implementation of Standards, which is intended to evaluate the achievement in each item of standard implementation. Control (C) from the Implementation of Standards, to conduct analysis of non-achievement of Standards so that corrections can be carried out for nonachievement of these Standards. Furthermore, Improvement Management (I), is a follow-up of the corrective steps/corrective actions so that the improvement will be carried out if corrections and/or corrective actions have been achieved.

The case study raised in this research is a case study in one of the Study Programs in one of the Departments in Polban. This Study Program has an A (excellent) accreditation rating through the BAN-PT form which at the time it did not require the implementation of IQAS. Specifically, this study program has standards related to the implementation of education standards, but has not been further studied for their suitability with the directives of Permenristekdikti No. 44 of 2015 [4] concerning National Standards for Higher Education and their compliance with indicators on the latest BAN-PT criteria [5]. Therefore a study is needed related to the implementation of IQAS in the Study Program so that the accreditation ranking as a superior study program can be maintained for accreditation in the coming years.

In answering and finding solutions to the problems expressed in the Introduction, the objectives and benefits to be achieved through this research are:

a. Completing IQAS documents required by study programs in implementing IQAS concretely through PIECI (Planning, Implementation, Evaluation, Control, and Improvement of Standards) management.

b. Synchronize and analyze IQAS standard indicators that are in line with the target of achieving study program accreditation according to the latest BAN-PT criteria (2019).

\section{Methods}

This research was conducted with descriptive and correlational methods. Descriptive method is carried out through data collection in detail, depth, and actual in order to explain the phenomena that exist. The correlational method is carried out through the study of the relationship between research variables so that these variables can be analyzed and then based on the analysis taken then the refinement phase and / or the preparation phase of the IQAS document are made at the Study Program level. In general, the stages of conducting research carried out are shown in Figure 1.

Data Inventory Stages are carried out to inventory IQAS documents from the Study Program, regulations related to higher education quality assurance both internal and external regulations, and the BAN-PT Accreditation Criteria especially those directly related to IQAS implementation. Stages of Data Analysis is a step to get a good analysis. At this stage, various data and rules that have been inventoried are firstly studied. After well studied and detailed, an analysis was carried out on the contents of the IQAS documents owned by the Study Program related to the existing regulations both from the substantive and administrative aspects. 
Document Refinement Phase is the synchronization stage of documents that are not in accordance with the Standards of Higher Education and BAN-PT indicators in the BAN-PT Accreditation Criteria. The documents that are suitable are then used as examples for the preparation of IQAS documents in other fields. The final stage, the stage for the Preparation of Guidelines, is carried out after all IQAS documents needed by the Study Program are well structured in accordance with the rules and indicators of BAN-PT accreditation. Furthermore, the preparation of IQAS implementation steps was carried out, especially in the context of fulfilling the regulations referred to (Higher Education Standards and 9 Accreditation Criteria of BAN-PT [5].

\section{Results and Discussion}

\subsection{Implementation of Quality Assurance System in Higher Education}

To be able to understand more clearly the results of the research carried out, it is necessary to firstly understand the Implementation of the Higher Education Quality Assurance System (HEQAS). In the HEQAS there are 3 (three) sub-systems, namely the Internal Quality Assurance System (IQAS), the External Quality Assurance System (EQAS) or Accreditation, and the Higher Education Database (HEDB) [2].

The legal basis for implementing the HEQAS is the Law No 12 year 2012 [1]. Article 51 of the Higher Education Law states that quality tertiary education is higher education that produces graduates who are able to actively develop their potential and produce Science and / or Technology that is useful for society, nation, and country. The government operates a higher education quality assurance system (HEQAS) to achieve qualified higher education, which means that higher education quality assurance is determined by the Minister and is a systemic activity to improve the quality of higher education in a planned and sustainable manner.

Figure 2.2 shows the mechanism for implementing HEQAS. The HEQAS mechanism is initiated by the Higher Education that implements IQAS through the PIECI activity cycle. This cycle consists of Planning (P) Higher Education Standards, Implementation (I) established Higher Education Standards, Evaluating (E) implementing Higher Education Standards to see achievement of Higher Education Standards, Control (C) implementation of HE Standards to analyze the non-achievement of HE Standards so that corrections can be carried out, and Improvement (I) of HE Standards, if an increase in standards has been reached so that it can be improved. The output of IQAS implementation in a cycle is conveyed by Higher Education to BAN-PT to request the Study Program's accreditation and obtain the Study Program's accreditation ranking in accordance with statutory provisions.

Universities and Polytechnics are required to report data and information on the fulfillment of HE Standards regularly to Kemenristekdikti through HE Data Base [6] to be evaluated through EQAS or accreditation in accordance with article 54 paragraph (6) of the Higher Education Law. Higher Education must manage their HE Data Base which has data and information structures that are identical to HE Data Base at the national level. HE Data Base in Higher Education integrated into National HE Data Base. Data and information on HE Data Base at the tertiary level are used by tertiary institutions for the implementation of IQAS in study programs and in tertiary institutions. The leader of the university and polytechnics are responsible for the completeness, correctness, accuracy, and up-to-date data on the organization of higher education that is reported to National HE Data Base. 


\subsection{Implementation of Quality Assurance System in Politeknik Negeri Bandung}

The implementation of quality assurance in Politeknik Negeri Bandung (Polban) has actually begun since the time this vocational education was established. Initially Polban implemented conventional higher education quality assurance, which was carried out through monitoring and evaluation as an IQAS implementation and through accreditation of all study programs as EQAS implementation. Furthermore, in response to the enactment of the 2003 National Education System Law [7], in 2005 Polban seriously started strengthening the implementation of IQAS and the Polban Quality Assurance Team was formed to handle the implementation of the internal quality assurance of Polban. At that time, many education institutions implemented quality assurance through the application of ISO 9001, so Polban chose to implement quality assurance through the application of ISO 9001: 2000. In each department, it was formed auditee representatives who guarantee the implementation of quality assurance in the Department and auditors who carry out audits in other Departments. This took place in the period of 2005 to 2008. In 2009 the implementation of quality assurance based on ISO 9001: 2008 which is also as an implementation of international quality assurance can be realized by obtaining an ISO 9001: 2008 Certificate on August 31, 2010 [8].

Furthermore, the implementation of quality assurance in Polban is coordinated through the Quality Assurance Unit (QAU) of the Politeknik Negeri Bandung (Polban) which was officially formed through the Charter of Establishment of the Polban QAU with Director's decision letter No. 0139 / R8.R / 2011. The Polban QAU is a functional work unit that reports directly to the Director and is led by a chairperson and is assisted by three coordinators in the field, namely the Internal Quality Assurance System (IQAS), the External Quality Assurance System (EQAS), and the Quality Assurance Database (QAD). In 2012, the government adopted a Law on Higher Education (Law No. 12 year 2012). This requires all higher education units (Higher Education) to run IQAS. Therefore Polban gradually and continuously makes improvements in the implementation of IQAS starting from the Polban level managed by QAU, the level of the Department managed by the Quality Assurance Group (QAG), and at the study program level managed by the Quality Assurance Team (QAT), although not yet fully effective. Figure 2.3 shows the IQAS implementation model at the Politeknik Negeri Bandung level.

The management of IQAS Polban implementation is designed to follow the PIECI model. Standards are established in advance through appropriate strategies and activities. Achievement of objectives / standards is monitored regularly, evaluated, and developed in a better direction on an ongoing basis. The IQAS Polban cycle is carried out with the concept set forth in Figure 2.4.

The PIECI model is applied in every line of Polban organization in which each unit periodically conducts a self-evaluation process to assess the performance of its own units using established standards and procedures. The results of the self-evaluation are reported to the head of the unit, all staff in the unit concerned, and to the head of the Polban. With respect to the results of the self-evaluation, the unit leader and the leader of the Polban make decisions regarding the actions that must be taken to maintain and improve their quality. The implementation of the PIECI model requires that each unit be open, cooperative, and ready to be audited by an internal auditor team, at least once a year. Audit results are recorded and reported to the head of the unit and head of the Polban, to take action based on the findings and recommendations of the auditor team.

Evaluations in the PIECI model under QAU coordination are realized in the Internal Quality Audit (IQA) activity which is carried out online once a year. The online IQA tool is 
named PAMIOL or the Polban Internal Quality Audit Online. IQA instruments include: (1) IQAS instruments intended for the Departments, (2) IIIA BAN-PT instruments for study programs and (3) derivative standard instruments for academic support work units. PAMIOL results are submitted to the leaders of the Polban (Directors and Assistant Directors) through the Management Review Meeting (MRM). MRM results are followed up in the next period under the PIC (person-in-charge) related to each work unit.

Every year Polban reports on the implementation of IQAS to the Ministry of Research, Technology and Higher Education (Kemenristekdikti) through "IQAS Mapping". Starting in 2019, all study programs also report IQAS performance evaluations to Kemenristekdikti online.

\subsection{Data Inventory}

Data inventory in this research includes inventory of IQAS Polban data / IQAS documents, IQAS of study programs studied, Regulations related to HEQAS, and Accreditation Criteria for BAN-PT. To understand the documents that are inventoried and synchronize with the Higher Education Standards (Dikti Standards) it is necessary to firstly explain the Dikti Standards. As stipulated in article 54 of the Directorate of Higher Education Law (Law No. 12 year 2012), the Directorate of Higher Education Standards consists of:

a. Higher Education National Standards (HE National Standards) established by the Minister, consisting of: National Education Standards coupled with Research Standards and Community Service Standards.

b. Higher Education Standards set by each tertiary institution with reference to the HE National Standards, consisting of Academic Field Standards and Non Academic Field Standards that exceed the HE National Standards.

Implementation of HE National Standards is regularly evaluated by the Minister. The results of the evaluation and standard marking are announced to the public. In particular, Kemenristek-Dikti has issued Permenristekdikti No. 442015 (Permenristekdikti 44 2015) which was perfected through Permenristekdikti No. 502018 (Permenristekdikti 50 2018). Figure 2.1. shows the HE National Standards Scheme and their exceedances.

According to Permenristekdikti no 32 year 2016 concerning Accreditation of Study Programs and Higher Education, Study Programs or Education Institutions that meet the HE National Standards, are declared to have accredited status. The quality of Study Program and Higher Education is not only measured by the fulfillment of each HE National Standards, but also by fulfillment of the interaction between HE National Standards [9].

The IQAS Polban documents and the Study Program (researched) documents that have been inventoried include 24 Core Higher Education Standards, namely 8 Education Standards, 8 Research Standards, and 8 Community Service Standards. Regulations related to HEQAS that have been inventoried include:

a. Law Number 12 year 2012 concerning Higher Education,

b. Permenristekdikti Number 44 year 2015 concerning National Standards for Higher Education,

c. Permenristekdikti Number 50 year 2018 concerning Changes to National Standards of Higher Education,

d. Permenristekdikti Number 32 year 2016 concerning Accreditation of Study Programs and Universities,

e. BAN-PT Regulation Number 2 year 2017 concerning the Higher Education National Accreditation System, and 
f. BAN-PT Regulation Number 2 year 2019 concerning Guidelines for Preparation of Self Evaluation Reports and Guidelines for Preparation of Study Program Performance Reports in Study Program Accreditation Instruments.

Furthermore, all these documents are used as a reference for the next stage, namely the analysis phase. Specifically, the BAN-PT accreditation criteria for the study program studied were assessed based on BAN-PT Regulations Number 2 of 2017 and Number 2 of 2019, and were assessed based on the Draft of Accreditation Assessment Matrix for Applied Undergraduate Study Programs.

\subsection{Data Analysis}

\subsubsection{Mapping of Polban Education Standards against Higher Education National Standards}

The results of mapping Polban Education Standards to Higher Education National Standards (HE National Standards) were very satisfying. Eight Polban Education Standards have met HE National Standard. All HE National Standard components have been accommodated in the Polban Education Standards.

Unlike Education Standards, based on mapping results, Polban Research Standards still do not fully meet HE National Standards. In the research standards, there are still some standard content components that do not meet the HE National Standards, especially matters related to student research. In HE National Standards, matters related to student research are regulated in research standards, but in Polban standards it has not been regulated on this matter. Whereas in reality, the research of Polban students has been carried out since the 2016 budget year, namely through the Student Creativity Program (SCP). The SCP in 2016 began with the Student Creativity Program - Intention Creation (SCP-IC) and the Student Creativity Research Program (SCP-RP). In the following year (2017) and up to 2019 one program has again been added in this SCP namely the Student Creativity Program - Scientific Articles (SCP-SA).

In addition, the results of research in the Polban standards have not yet been explicitly explained in their forms, whereas in HE National Standard, it has been detailed about the forms of dissemination of research results. For this reason, the Polban Research Standards need to be revised to meet all HE National Standard components.

The results of mapping for the Polban Community Service Standards to the HE National Standards show that not all HE national standard components are accommodated in the Internal Polban Standards. The level of depth and breadth of community service materials in the Content Standards has not been well detailed. In the Polban Community Service Implementation Standards, the results of previous community services have not even been written as a base line. This is contrary to the implementation of the community services in reality. For this reason, the Polban Community Service Standards need to be revised to accommodate all HE National Standard components

Subsequent data analysis includes analysis of the results of Polban Standards mapping to the Study Program Accreditation Instruments Criteria 1 to Criteria 9. This is conducted so that the value of accreditation to be obtained by the Study Program is the maximum value in each criterion. As explained in the Research Objectives that the accreditation target to be achieved by the Study Program is the excellent accreditation.

The results of the mapping of Polban Standards to the Study Program Accreditation Instrument Criteria 1 shows that the indicators of all elements (Vision, Mission, Objectives, 
and Strategy/VMOS) have not indicated that an excellent accreditation score will be obtained. Actually, the inclusion of Polban Vision and Mission in Poban Standards is only limited to the standard document format that is followed. In general, the vision and mission become the starting point in determining all standards in the Polban. For this reason, a number of things are needed to improve Polban Standards, including:

a. Data needs to be prepared related to the consistency and implementation of VMOS in Polban activities,

b. Need to prepare documentation on the preparation of VMOS that involves all stakeholders,

c. It is necessary to prepare documentation of strategies for achieving goals and the follow-up monitoring and evaluation

d. It should be written in the standard that all components of the standard have been based on the achievement of VMOS and its implementation is constantly monitored, evaluated, and acted upon.

\subsubsection{Mapping of Polban Standards on the Study Program Accreditation Instrument Criteria 2}

There are 7 (seven) elements in Criteria 2 that must be accommodated in the Polban Standards which include Civil Service Governance, Leadership and Managerial Ability, Cooperation, Additional Performance Indicators, Evaluation of Performance Achievement, Quality Assurance, and Stakeholder Satisfaction. Not all indicators on each element are accommodated in the Polban Standards which indicate the excellence accreditation score will be obtained. Several things that are needed in improving the Polban standarda include:

a. The organizational structure of Polban, department, and study program need to be included in one of the standard supplementary documents, for example in the standard implementation manual;

b. Criteria for civil service governance can be explained in the definition of terms in the standard;

c. The operational, organizational, and public leadership characteristics can be added to the definitions section of terms in standard documents. Evidence of leadership documentation and managerial skills of Polban or Department leaders can be prepared;

d. Explanation of the 6 functions of the Department leaders can be completed in the definition of terms in standard documents. Documentary evidence also needs to be prepared;

e. Polban and Department standards need to be supplemented with an explanation of the quality, benefits, satisfaction and sustainability of the collaboration and how to measure it

f. Department needs to prepare standards outside the 24 core standards that have been owned by Polban as a form of exceeding HE National Standards.

g. The results of evaluation and analysis need to be presented in the standard

h. Internal quality assurance documents at the Departmet level need to be completed

i. It is necessary to prepare instruments for measuring service satisfaction that are accompanied by follow-up steps to the results of these measurements. 


\subsubsection{Mapping of Polban Standards on the Study Program Accreditation Instrument Criteria 3}

Criteria 3 cover the Quality of Student Input, Study Program Attraction, and Student Services. Several things that are needed in the improvement of the Polban Standards to obtain maximum value in this Criteria 3 include:

a. Compilation of student standards, starting from the recruitment process to student services,

b. Student recruitment standards need to include a target ratio of the number of applicants to the number of students accepted,

c. Student standards need to include the uniqueness of existing study programs and the target of increasing the number of registrants, so that they can reflect the increase in student interest,

d. Several study programs at Polban have received international accreditation which allows them to accept foreign students. It is necessary to prepare policies and instruments for conducting lectures for foreign students,

e. Student standards also need to contain what types of services can be obtained by Polban students,

f. Student standards need to include access and quality of student services.

\subsubsection{Mapping of Polban Standards on the Study Program Accreditation Instrument Criteria 4}

Criteria 4 cover elements related to Human Resources (HR). There are 19 indicators in the Study Program Assessment Matrix. From the mapping of Polban Standards to these 19 indicators, it can be concluded that several things need to be improved so that the Study Program can obtain maximum value in these Criteria 4, namely:

a. Minimum number of permanent lecturers per study program,

b. Percentage of lecturers with final linear education qualifications,

c. Percentage of S3 lecturers qualified,

d. Percentage of certified lecturers,

e. Percentage of certified teaching staff,

f. Percentage of lecturers with Associate Professor and Professor functional positions,

g. The ratio of the number of lecturers to students,

h. Average number of student guidance per lecturer (main supervisor),

i. Total tridarma credits,

j. Percentage of non-permanent lecturers,

k. Percentage of competency courses supported by industry lecturers,

1. The number of lecturers who received recognition of their achievements / performance,

m. The number of lecturers who have research relevant to the field of study program,

n. Number of lecturers who have community services that are relevant to the field of study program,

o. Number of lecturers who have scientific publications with themes relevant to the field of study program,

p. The number of lecturers who have cited articles,

q. Number of lecturers' products / services adopted by industry / society,

r. Number of research outcomes,

s. Efforts to develop lecturers,

t. Qualifications and adequacy of education personnel, and 
u. Laboratory qualifications and adequacy.

\subsubsection{Mapping of Polban Standards on the Study Program Accreditation Instrument Criteria 5}

There are 6 (six) indicators in the Assessment Matrix to obtain the maximum value of accreditation in the elements of Finance, Facilities and Infrastructure in this Criteria 5. The results of the mapping of Polban Standards to the Study Program Accreditation Instrument in Criteria 5 require some improvements to be able to obtain maximum scores, including:

a. Annual operational funds,

b. Allocation of research funds per Permanent Lecturer of Study Programs per year,

c. Community service fund allocation per Permanent Lecturer of Study Programs per year,

d. Realization of investments that support the implementation of Tridarma,

e. Criteria for funding adequacy in achieving learning outcomes,

f. Criteria for the adequacy of accessibility and quality of infrastructure.

\subsubsection{Mapping of Polban Standards on the Study Program Accreditation Instrument Criteria 6}

Criteria 6 cover Education, where the 20 elements listed in Criteria 6 are not all accommodated in the Polban Standards. Several indicators needed to improve the Polban Standards include:

a. Online learning,

b. Monitoring and evaluating the implementation of the learning process,

c. Elements of conducting research,

d. Integration of research activities and community services in learning,

e. Implementation of structured learning programs and activities to improve the academic atmosphere on a regular basis,

f. The level of student satisfaction with the education process,

g. Analysis and follow-up of the results of student satisfaction measurements.

\subsubsection{Mapping of Polban Standards on the Study Program Accreditation Instrument Criteria 7}

The results of mapping the Polban Standards to the Study Program Accreditation Instrument Criteria 7 (Research) have not yet been met to obtain the maximum score. In general, the relevance of research in the Study Program Management Unit (Department) has met 4 kinds of indicators namely having a research road map, the research carried out refers to the road map, evaluating the suitability of the study with the road map, and using the evaluation results to improve the relevance of the research and scientific development program. However, in its implementation it has been carried out by individual lecturers. Likewise, in fulfilling the indicators of the Study Program Permanent Lecturer which in its implementation involves study program students have not yet been fully met. The ratio of student involvement in lecturer research has not yet been determined by its standards. 


\subsubsection{Mapping of Polban Standards on the Study Program Accreditation Instrument Criteria 8}

Criteria 8 cover Community Services. Like Criteria 7, the mapping of Polban Standards to the Study Program Accreditation Instrument Criteria 8 has not met the maximum score. Although in general, it has fulfilled 4 kinds of indicators on the points of relevance of community services in the Department, but in the new implementation carried out by individual lecturers. Likewise, in fulfiling the community services indicators of Permanent Lecturers of Study Programs, which in their implementation involves Study Program students, they have not yet been fully met. The ratio of student involvement in lecturer community services has also not been determined by its standards.

\subsubsection{Mapping of Polban Standards on the Study Program Accreditation Instrument Criteria 9}

Based on the results of the mapping of Polban Standards to the Study Program Accreditation Instrument Criteria 9, there are several indicators that need to be fulfiled in order to obtain the maximum value of accreditation, including:

a. Analysis methods for fulfilling graduate learning outcomes (CPL),

b. Improved graduate GPA standards,

c. Number of student academic achievements,

d. Number of non-academic achievements of students,

e. Study period,

f. Percentage of study success,

g. Implementation of tracer study,

h. The level and size of the graduate workplace,

i. The level of user satisfaction of graduates,

j. Student participation in scientific performances/exhibitions/ presentations/publications,

k. Products / services of student work adopted by industry/society,

1. Research and community services outcomes.

\subsection{Completion of Study Program Standard Documents}

The mapping analysis of existing Standards with the HE National Standards and the Study Program Accreditation Assessment Matrix described above is then used to perfect the Study Program Standards document. In this study, the IQAS document was perfected for one of the Standards, namely Graduates Competency Standards. This document is then used as a reference for refinement of the other Standards.

\subsection{Development of Guidelines}

The preparation of the Guidelines is the final stage of this research. Of all the Standards that have been refined in the previous stage, it is possible to compile an IQAS Document that includes the HE National Standard Criteria in accordance with Permenristekdikti 44/2015 and Permenristekdikti 50/2018. The IQAS output will then become an input for EQAS/Study Program Accreditation. Therefore, IQAS must be implemented well, up to the level of the Study Program. The implementation of IQAS requires IQAS documents (IQAS Policy, Standards in IQAS, IQAS Manual, and Forms). In order to achieve that every Study Program 
can carry out the IQAS perfectly, it is necessary to provide the IQAS Implementation Guidelines. The Head of the Department needs to establish IQAS documents which must be implemented at the Study Program level. The IQAS implementation is prepared by the Head of the Study Program in accordance with the direction of the Head of the Department. The IQAS implementation procedure is carried out by following the steps shown in Figure 4.1.

\section{Conclusion}

Some conclusions that can be drawn from the results of this study are:

a. IQAS documents owned by Politeknik Negeri Bandung still need to be refined to include the HE National Standards Criteria in accordance with Permenristek-Dikti 44/2015 and Permenristekdikti 50/2018,

b. IQAS documents of the Study Program Management Unit (Department) can be prepared by considering the uniqueness of the Study Program and exceeding the Higher Education Standards,

c. Indicators in the IQAS documents can be completed in accordance with the results of the mapping of Internal Standards to the HE National Standards and Study Program Accreditation Matrix.

\section{Acknowledgements}

Acknowledgments were conveyed to Research and Comunity Services Unit, Politeknik Negeri Bandung for research funding in accordance with Research Implementation Agreement Letter No. 350.19 / PL1.R7 / LT / 2019.

\section{References}

[1] Republic of Indonesia: Law Number 12, Higher Education. Jakarta (2012)

[2] Ministry of Research, Technology, and Higher Education: Permenristekdikti Number 62, Higher Education Quality Assurance (2016)

[3] Directorate of Quality Assurance, Ministry of Research, Technology, and Higher Education: Mapping of Internal Quality Assurance System (2018)

[4] Ministry of Research, Technology, and Higher Education: Permenristekdikti Number 44, National Standards of Higher Education (2015)

[5] BAN-PT: Regulation Number 3, Higher Education Accreditation Instruments (2019)

[6] Ministry of Research, Technology, and Higher Education: Permenristekdikti Number 61, Higher Education Database (2016)

[7] Republic of Indonesia: Law Number 20, National Education System. Jakarta (2003)

[8] Budiastuti, H., E. Sutjiredjeki, L.O. Astuti: $8^{\text {th }}$ SCBTII Proceeding Telkom University, Quality Assurance System in Politeknik Negeri Bandung: Experience in 2005 - 2017 (2017)

[9] Ministry of Research, Technology, and Higher Education: Permenristekdikti Number 32, Accreditation of Study Programs and Higher Education Institutions (2016) 